\title{
Značilno vedenje otrok prvega starostnega obdobja v igralnicah z različno glasbo
}

\author{
Barbara Kopačin \\ Univerza na Primorskem \\ barbara.kopacin@pef.upr.si
}

Danes je glasba kot psihološki pojav v vsakdanjem življenju razširjena in vsem dostopna kot še nikoli prej. Poslušamo jo lahko v avtu, preko pametnih telefonov skozi slušalke, preko radijskih ali televizijskih sprejemnikov ... Glasbo, ki jo poslušamo, si lahko izberemo tudi sami. Ali si jo otroci prve starostne skupine v vrtcu lahko tudi sami izberejo? Tam glasbo izbirajo vzgojitelji. Od njih pričakujemo, da imajo razvite glasbene sposobnosti, spretnosti, glasbeno ustvarjalnost in znanje, torej vse tiste glasbene sposobnosti, ki so pomembne za uspešen otrokov glasbeni razvoj. V katerih igralnicah z raznovrstno glasbo v ozadju se otroci najdlje zadržujejo, smo ugotavljali z raziskavo, ki je potekala v petih primorskih vrtcih. $V$ raziskavi je sodelovalo 66 otrok prve starostne skupine. $\mathrm{Na}$ izbiro smo jim dali tri glasbene zvrsti. V treh igralnicah, kjer smo izvajali glasbo, so bile otrokom na razpolago različne namizne igre. Ugotovili smo, da so se otroci najraje zadrževali v igralnici, kjer so lahko poslušali otroške pesmi.

Ključne besede: otrokov celostni razvoj do tretjega leta starosti, otrokov glasbeni razvoj do tretjega leta starosti, glasbena vzgoja v vrtcih, poslušanje glasbe

\section{Uvod}

Otrok že v materinem telesu dobiva sporočila iz okolja preko zvoka in nanje tudi reagira. Ta spoznanja moramo upoštevati pri pripravi in vodenju glasbenih dejavnosti v vrtcu. Otroku bi morali vzgojitelji v vrtcu omogočati, da skozi umetnost izraža svoj intimni svet in z okoljem komunicira spontano, neposredno in individualno.

Glasbena dejavnost poslušanje glasbe v vrtcu zahteva specifične učne metode in oblike dela. Poslušamo vse glasbene zvrsti, od ljudske do umetne glasbe vseh stilnih obdobij in v različnih vokalnih, vokalno-instrumentalnih ali instrumentalnih zasedbah. Sposobnost zaznavanja glasbe pa nam ni dana sama po sebi, ampak se je moramo naučiti.

\section{Teoretična izhodišča}

Prvi zvoki, s katerimi se otrok sreča, so enakomeren utrip krvi, ki teče po materinem telesu, dviganje in upadanje pri njenem dihanju, globoko basovsko 
bobnenje trebuha, premiki tekočine $v$ maternici in $v$ ozadju vsega tega materin srčni utrip.

Prvo čutilo, ki se razvije pri zarodku, je uho. Slušni živec, ki prenaša informacije iz ušesa v možgane, je prvi telesni čutni živec, ki začne delovati. V plodovem slušnem sistemu so približno v petem mesecu povezave toliko dozorele, da možganom omogočajo celovito obdelavo zvoka. Ko je plod v maternici sposoben slišati, ne le aktivno posluša, ampak se od tistega, kar sliši, tudi uči. Še nerojeni otrok je že sposoben sprejemati zvočne informacije, si jih zapomniti in jih priklicati iz spomina tudi po rojstvu (Clinic 2001; Campbell 2004).

$S$ poslušanjem glasbe vplivamo na otrokov emocionalni razvoj, razvoj estetske kulture in glasbenih sposobnosti (Denac 2002). Otrok že v predšolskem obdobju raziskuje zvoke. Ob ustvarjanju na improvizirane in lastne instrumente raziskuje različne barve, glasnosti, trajanja in višine zvokov. Na ta način pridobiva prve izkušnje s poslušanjem glasbe. Otrok lahko posluša vokalno, instrumentalno ali vokalno-instrumentalno glasbo. Ponudimo pa mu lahko tudi glasbene pravljice ter zvoke iz narave in okolja (Borota 2013).

Glasbo lahko poslušamo na različne načine: (i) doživljajsko poslušanje; (ii) doživljajsko-analitično poslušanje in (iii) analitično poslušanje. $V$ predšolskem obdobju je osrednji način poslušanja glasbe doživljajski, saj otroku omogoča doživeto in poglobljeno poslušanje; predvsem pa mu spodbudi različna razpoloženja in čustvene odzive (Borota 2013). Hkrati s poslušanjem otroku lahko omogočimo tudi izražanje teh doživetij preko gibanja, slikanja ali izražanja $z$ besedo. Mlajši predšolski otroci doživetja in predstave glasbenih del najpogosteje izražajo gibalno (Denac 2010).

\section{Celostni razvoj otrok do tretjega leta starosti}

Razvoj otroka poteka celostno in usklajeno na gibalnem, telesnem, miselnem, čustvenem in socialnem področju. Poteka približno v enakih obdobjih, za katera je značilno tipično vedenje otrok (Gallahue in Ozmun 2006 v Videmšek in Pišot 2007).

M. Videmšek, P. Berdajs in Karpljuk (2003) otrokov razvoj opredeljujejo kot dinamičen proces, ki ga $v$ medsebojni povezanosti opredeljujeta dednost in okolje. Avtorji menijo, da se na vse dejavnosti otrokovega razvoja ne da vplivati enako.

Otrok je ob rojstvu popolnoma odvisen od odraslega človeka in okolja, $v$ katerem se je znašel. Najprej je to njegova družina, $v$ kateri se nauči prvih medsebojnih odnosov. Naslednje je okolje, v katerem se gibljejo njegovi starši v razširjeni družini in med prijatelji. Tik pred dopolnjenim prvim letom pa otrok navadno vstopi v vrtec, kjer se sreča z vzgojitelji in s svojimi vrstniki, 
s čimer se njegov socialni krog razširi. Oblikujejo se nove povezave, nov način življenja in reševanja težav (Kranjc 2011).

Med pomembnejše otrokove razvoje uvrščamo ravno socialni in čustveni razvoj, saj pripomoreta k razvoju v odraslo osebo, ki je pripravljena na spoznavanje in razumevanje sveta. Pomembno pa je, da pri otroku vsi, ki smo vključeni v njegovo vzgojo, razvijamo pozitivna čustva, kot so veselje, ljubezen, občutek varnost ... S poznavanjem in sprejetjem teh čustev lahko razvijamo socialna čustva, kot so prijaznost, dobrota, obzirnost ... (Benkovič 2011).

Poznamo veliko različnih teorij o razlagi čustev. Vsem je skupno to, da slednja razumejo kot skupek zaporednih dražljajev in odzivov, ki si sledijo v določenem vrstnem redu. Na čustva otrok vpliva tudi odnos med starši in zgled, ki ga posredujejo svojemu otroku (Kožman 2011).

Otroci, ki kažejo v večji meri pozitivna čustva, bolj sodelujejo v vsakdanjih situacijah. Nasprotno je otroke, ki so potrti in večinoma slabe volje, težje motivirati za dejavnosti. Socialno kompetentni otroci sodelujejo v vsakodnevnih dejavnostih in se radi igrajo s svojimi vrstniki. Take otroke si tudi vrstniki izbirajo v svoj ožji krog. L. Marjanovič Umek in M. Zupančič (2009) prepoznavata, da so deklice odprtejše in komunikativnejše in zaradi tega tudi socialno kompetentnejše kot dečki.

Gibalni razvoj vsakega otroka poteka po nekem določenem zaporedju. Najprej sedi, nato stoji in šele nato hodi. Hitrost gibalnega razvoja je individualna. Otrok najprej usvaja osnovne oblike gibanja, ki jih počasi avtomatizira, in zaključi z gibanjem, ki ga otrok obvlada v različnih okoliščinah in situacijah. M. Videmšek in Pišot (2007) gibalni razvoj opredeljujeta kot proces, s pomočjo katerega otrok pridobiva gibalne spretnosti in vzorce, kar je rezultat medsebojne povezanosti dednosti in okolja. Dani vplivi so pomembni za mišično zorenje, med okoljskimi dejavniki pa imajo najpomembnejši vpliv predhodne gibalne izkušnje, tudi iz predporodnega obdobja. Otrok skozi vsakodnevne dejavnosti in igro pridobiva gibalne spretnosti in uri svoje gibalne sposobnosti. Najraje se igra na prostem in s svojimi vrstniki. Ves čas aktivno raziskuje svoje zmožnosti in okolico. Človekov gibalni razvoj se torej začne že $\checkmark$ predrojstvenem obdobju in se neprestano izpopolnjuje $v$ nadaljnjem razvoju. Še posebno izrazit je v prvih treh letih življenja. Starejši kot je otrok, kompleksnejša gibanja uporablja. Na rast in telesni razvoj v veliki meri vpliva gibanje (Videmšek in Pišot 2007).

V prvem starostnem obdobju govor otroka nekoliko sunkovito napreduje. Najprej šele spoznavajo besede, ki jih povezujejo s predmeti in dejanji. Do tretjega leta starosti pa otroci že sestavljajo enostavčne povedi in besede povezujejo med seboj (Marjanovič Umek in Zupančič 2001). 


\section{Glasbeni razvoj otrok do tretjega leta starosti}

Znanstveno je dokazano tudi, da se vsak otrok rodi z nagnjenji do glasbe, ki se lahko $v$ prvem letu življenja $v$ ugodnih razmerah razvijejo $v$ elementarne sposobnosti, v neugodnih pa zakrnijo. To je odvisno od treh dejavnikov: prvi je otroški svet s svojimi razvojnimi periodami in duševnimi sprejemljivostmi, drugi sta okolje in družba s svojimi načeli vzgojnega usmerjevanja, tretji pa je glasba s svojimi tonskimi fenomeni (Šivic 1975).

Glasbeni razvoj je zapleten in kompleksen proces, ki ga je težko do potankosti spoznati in razložiti. Prav v njem so med ljudmi največje individualne razlike. Je pomembno odvisen od številnih dejavnikov, ki ga podpirajo ali zavirajo, podobno kot razvoj otrokovega mišljenja, saj je z njim tesno povezan. Poglavitne značilnosti in zakonitosti psihičnega razvoja veljajo tudi za glasbeni razvoj, zato ga lahko razložimo tudi z nekaterimi razvojnimi teorijami in njihovimi znanstvenimi izsledki. Nekatere raziskovalne metode preučevanja psihičnega razvoja otroka so psihologi aplicirali tudi na preučevanje glasbenega razvoja (Wing 1961; Lundin 1967).

Največji vpliv na glasbeni razvoj v obdobju dojenčka in malčka ima tako družinsko kot širše socialno okolje. Kritično obdobje za razvoj občutljivosti za glasbo traja od rojstva do drugega leta, zato ga moramo podpreti z ustreznimi spodbudami iz okolja in dojenčkom ter malčkom omogočiti čim pogostejši stik z glasbo (Starc in Markočić 2004).

Opisati splošne stopnje otrokovega glasbenega razvoja po bioloških starostnih obdobjih je zelo težko ali skoraj nemogoče, saj so glasbene lastnosti kompleksne in večdimenzionalne, sestavljene iz različnih glasbenih sposobnosti. Pri mnogih otrocih se določene glasbene sposobnosti pokažejo prej, pri drugih pa lahko kasneje. Zato ni mogoče povsem natančno predvideti, kdaj se določena glasbena sposobnost lahko razvije in kdaj ne. Napredovanje otrok iz enega stadija v drugi poteka individualno.

Glasbene sposobnosti delimo na elementarne glasbene sposobnosti (melodični in ritmični posluh) in sposobnosti višjega reda (harmonski posluh, analitično poslušanje in sposobnosti estetskega oblikovanja in vrednotenja). Za otrokov razvoj je pomemben razvoj melodičnega in ritmičnega posluha, saj je to osnova za razvoj sposobnosti višjega reda (Sicherl Kafol 2001).

Vidimo, da strnjen pregled glasbenega razvoja po starostnih obdobjih predstavlja le ogrodje. To velja tudi za podatke o stopnji razvoja glasbenih sposobnosti po starostnih obdobjih le do četrtega leta starosti, ki sta ga podala R. Shuter-Dyson in Gabriel (1981 v Slosar 1995) (preglednica 1).

Danes je veliko govora o glasbenem razvoju že v predrojstvenem obdobju, 
Preglednica 1 Pregled glasbenega razvoja otrok do četrtega leta starosti

\begin{tabular}{ll}
\hline Starost v letih & Stopnje razvoja \\
\hline $0-1$ & Reakcije na zvok \\
$1-2$ & Spontano ustvarjanje glasbe \\
$2-3$ & Pričetek produciranja pesmi, ki jih otrok sliši \\
$3-4$ & Ustvarjanje splošnega načrta melodije \\
& razvoj absolutnega posluha, če se otrok uči igranja na instrument \\
\hline
\end{tabular}

Opombe Povzeto po Shuter-Dyson in Gabriel (1981 v Slosar 1995, 29).

ko se nerojeni otrok odziva na zvok in glasbene spodbude. Odzive na glasbo opažamo pri novorojenčku, ko se v prvih dneh življenja vidno obrača za zvočilom. Na fiziološki ravni so spremembe vidne v intenziteti dihanja in pospešenem bitju srca. Od tretjega meseca se otrok aktivno odziva na glasbo, ko se začne obračati k izvoru zvoka in premikati v ritmu glasbe (Smolej 1996).

Otroci okrog šestega meseca starosti začno že aktivno reagirati na glasbo. Obračajo se proti zvočilu in kažejo zadovoljstvo ali čudenje. Kmalu po šestem mesecu starosti se začnejo ob glasbi gibati - zibati. Po šestem mesecu se začnejo pojavljati poskusi ponavljanja zunanjih zvočnih vtisov - najprej z grobo imitacijo posameznih zlogov, nato njihovo podvajanje in ponavljanje, v katerem opazimo že spremembe v višini in ritmu. Ostwald (1973 v Slosar 1995) meni, da otroci z »vokalno igro« raziskujejo rang višin tonov glede na svoj glasovni obseg. Revesz (1954 v Slosar 1995) pa je prepričan, da otroci poskušajo imitirati tone, ki so jih slišali.

Hargreavesova (1990 v Slosar 1995) študija razvoja spontanega petja govori o tem, da je v začetni fazi sestavljeno iz kratkih melodičnih fraz, brez fiksiranih tonskih višin v malih nenatančnih intervalih, ki se ponavljajo $v$ nedogled. Melodičen in ritmičen obris motiva v grobem ostaja nespremenjen, spreminjajo se tonska višine. Sposobnost natančnega razlikovanja tonov po višini se razvija postopno. Triletni in štiriletni otroci imajo še težave pri razlikovanju tonov po višini.

Velik napredek v glasbenem razvoju poleg gibnega pomeni še zvočno odzivanje na glasbene dražljaje. To se zgodi v prvem letu starosti. Te zvočne reakcije otroka na glasbo Moog (1976 v Slosar 1995) imenuje glasbeno čebljanje. Sestavljeno je iz tonov različnih višin, izvedenih na enem vokalu ali na manjšem številu zlogov. Nadalje ugotavlja, da melodije glasbenega čebljanja ne kažejo podobnosti s poslušano glasbo in nimajo še jasne melodične in ne ritmične organizacije, pavze so npr. tam, kjer se je pojavila potreba po vdihu.

$V$ drugem letu starosti se močno povečata količina in raznovrstnost gib- 
nega reagiranja na glasbo. Oblike gibanja so različne (nihanje stopala, dviganje in spuščanje pet, premikanje kolen itd.). Med tretjim in četrtim letom prevzame dominirajočo vlogo nad gibom petje, čeprav je gibanje še vedno pomembna oblika odzivanja na glasbo. Petje $v$ tem obdobju namreč postane del domišljijskih iger (Piaget 1952 v Slosar 1995). Čeprav se količina gibanja, povezanega z glasbo, s starostjo zmanjšuje, se njegova pestrost povečuje; izboljšuje se koordinacija gib - glasba in gib - gib, ki prerašča v prepoznavne plesne korake. Proti koncu drugega leta starosti začno otroci v svoje »spontane pesmi« vključevati $z$ učenjem pridobljene ritmične in melodične vzorce (iz »učenih« otroških pesmi). McKernon (1979 v Slosar 1995) ugotavlja, da otrok pri triindvajsetem mesecu starosti povzame že ritmični vzorec, pri katerem sledi dvema kratkima tonoma en daljši ton.

Proces razvoja "spontane pesmi « lahko razložimo s Piagetovo teorijo asimilacije in akomodacije (Piaget 1952 v Slosar 1995). Otrok glasbene elemente iz okolja asimilira v svojo shemo »spontane pesmi«. Če otrok teh glasbenih vzorcev ne more asimilirati v svoje že obstoječe sheme, ustvari nove sheme - proces akomodacije. Na ta način se obris otrokove spontane pesmi vedno bolj približuje oblikam naučenih pesmi. Tako otrok ustvarja nove pesmi, ki jih Moog (1976 v Slosar 1995) imenuje pesmi »pot-pourri«. To so pesmi, ki imajo izposojen ali ritem ali melodijo ali pa tudi dele besedila; to so nekakšna zlitja in kombinacije spontanih in naučenih pesmi. Vendar spontanega ustvarjanja pesmi otroci ne opustijo kljub temu, da znajo zapeti že nekaj naučenih otroških pesmi. Gojijo ga dalje in vanj vnašajo vedno več $z$ učenjem pridobljenih glasbenih elementov. McKernon (1979 v Slosar 1995) ugotavlja, da spontane pesmi ostanejo melodično neorganizirane tudi pri štiriletnih otrocih kljub vplivom glasbenega učenja. Dokaj hitro pa se naučijo "standardno« otroško pesem. Približno polovica triletnih otrok je sposobnih bolj ali manj natančnega imitiranja vseh treh elementov pesmi: besedila, ritma in melodije. Dominantno vlogo ima sicer besedilo, ritem in melodija sta še nekaj bolj »abstraktnega«.

Pri otrocih v predšolskem obdobju harmonski posluh še ni razvit, zato je pomembno, da otrok sliši tudi večglasno petje, na osnovi katerega se razvijajo tudi dispozicije za nadaljnji razvoj harmonskega posluha (Denac 2002).

\section{Glasbena vzgoja v vrtcu}

Dnevne programe $v$ javnih vrtcih vzgojitelji in pomočniki vzgojiteljev oblikujejo po Kurikulumu za vrtce (Ministrstvo za šolstvo in šport 1999), ki je nacionalni dokument in ima svojo osnovo $\mathrm{v}$ analizah, predlogih ter rešitvah, $\mathrm{ki}$ so uokvirile koncept in sistem predšolske vzgoje $v$ vrtcih. $V$ njem so prepo- 
znavna tako temeljna načela in cilji predšolske vzgoje kot tudi spoznanja, da otrok svet dojema in razume celostno, da se razvija in uči v aktivni povezavi s svojim socialnim in fizičnim okoljem ter da v vrtcu v povezavi z vrstniki in odraslimi razvija lastno družbenost in individualnost. Glasba je zajeta v poglavju Umetnost, ki zajema tudi likovne, plesne in dramske dejavnosti. Kurikulum navaja, da se otrokovi potenciali kažejo v igrivem raziskovanju in spoznavanju sveta, saj v umetnosti izumlja in ustvarja, ko odkriva jezikovne strukture, artikulira vsebine, si zamišlja in oblikuje sliko, pesem, igro, ples in predmet. Otroška umetniška dela nastajajo, ko ima otrok pri delu svobodo in se od njega pričakujejo neposrednost, drugačnost, izvirnost.

V Kurikulumu za vrtce (Ministrstvo za šolstvo in šport 1999) so predstavljeni primeri glasbenih dejavnosti v vrtcih, ki naj bi jih otroci delali v prvi starostni skupini: (i) s petjem, z igranjem, s poslušanjem in z izmišljanjem glasbe glasbo doživlja, poustvarja, ustvarja, se z njo izraža in komunicira; (ii) ritmično izreka enostavne ljudske in otroške izštevanke in šaljivke; (iii) petje in ritmično izreko spremlja z glasbili in gibanjem; (iv) posluša, posnema in razlikuje zvoke iz narave in okolja; (v) posluša izvedbe in posnetke izbranih del glasbene literature; (vi) poje otroške, ljudske in umetne pesmi v obsegu svojega glasu; (vii) izvaja ritmične vzorce s ploskanjem, topotanjem, tleskanjem, udarjanjem ... in igranjem na mala glasbila; (viii) spontano si izmišlja ritmično-melodične vzorce; (ix) doživlja in opazuje igranje ter petje odraslega in starejših otrok; $(x)$ posluša glasbene pravljice in sodeluje $v$ njih.

Na področju umetnosti bi morali pri izvajanju dejavnosti vsi, ki jim je zaupano vzgojno delo v vrtcu, upoštevati razvojne zakonitosti otroka in značilnosti otroka na posameznih umetniških področjih, ki se pri posamezniku odražajo na individualen način. Prav bi bilo, da se v vrtčevski skupni, kjer prebijejo otroci kar nekaj ur dnevno, oblikuje bogato in raznovrstno umetniško (glasbeno, likovno, gledališko, plesno) okolje z različnimi spodbudami, ki otroku omogočajo doživljanje sebe in drugih, okolice in umetnosti. Kakovostno estetsko in umetniško okolje tudi sooblikuje otrokov razvoj estetskega vrednotenja ter osebnega okusa.

Glede na pestrost odzivov na glasbo in reagiranja otrok do tretjega leta starosti s področja petja, igranja na glasbila za otroke, poslušanja in ustvarjanja nas je $v$ naši raziskavi zanimalo področje poslušanja glasbe.

\section{Empirični del}

\section{Opredelitev problema, namen in cilji raziskave}

Danes nas, bolj kot kdajkoli prej, na vsakem koraku obdajajo zvoki in glasba različnih zvrsti. Doma si lahko sami izberemo glasbo, ki jo želimo poslušati, v 
avtu tudi; na avtobusu, $v$ trgovini, na sprehodu po mestu ... pa nam glasbo izberejo drugi. Največkrat te zvočne kulise ne poslušamo zavedno. Ob tem se nam zastavlja vprašanje, kako je s poslušanjem glasbe v vrtcu oz. kaj je značilno za glasbo $v$ ozadju v igralnicah za otroke prvega starostnega obdobja.

Z raziskavo, ki smo jo izvedli, smo želeli ugotoviti, koliko časa se otrok zadržuje ob igri v igralnicah z različno glasbo kot zvočno kuliso in kaj je za otrokovo vedenje $v$ igralnicah $z$ različno glasbo značilno. Glede na namen raziskave smo oblikovali dva cilja:

1. Opazovati in beležiti vedenja otrok v igralnici s stalno prisotnostjo namiznih iger ob glasbi kot zvočni kulisi.

2. Beležiti čas zadrževanja otrok v posamezni igralnici, kjer so se predvajale različne zvrsti glasbe.

\section{Raziskovalni vprašanji}

Na podlagi oblikovanih ciljev raziskave smo si postavili raziskovalni vprašanji:

1. Katere so značilnosti otrokovega vedenja v igralnicah z različnimi zvrstmi glasbe $v$ ozadju?

2. V katerih igralnicah z glasbo v ozadju se otroci najdlje zadržujejo?

\section{Metodologija}

V okviru kvalitativnega pristopa se lahko posvetimo posameznemu primeru (skupina, družina, razred ...), ki ga raziščemo in opišemo v obliki študije primera. Študija primera je celovit opis posameznega primera in njegova analiza, opis značilnosti in dogajanja ter opis procesa odkrivanja teh značilnosti (Mesec 1998). V naši študiji primera obravnavamo, kako so se otroci prve starostne skupine vedli v igralnicah, kjer se je predvajala različna glasba. Vzgojiteljice so merile in si zapisovale čas zadrževanja vsakega otroka v posamezni igralnici, kolikokrat so se vračali v posamezno igralnico, kaj so otroci ob poslušanju zvočne kulise počeli ter reakcije otrok ob slišani glasbi (petje pesmic, gibanje, ples z drugimi otroki ...).

Raziskavo, v kateri je sodelovalo 66 otrok prve starostne skupine, smo izvajali v petih vrtcih na Primorskem. Med otroki, ki so sodelovali v raziskavi, so bili le trije $v$ raziskavo vkljčeni otroci (4,55-odstotni delež) mlajši od enega leta. Do enega leta in pol starih otrok, sodelujočih v raziskavi, je bilo 16 ali 24,24-odstotni delež vzorca. Otrok, starih med enim letom in pol ter dvema letoma, je v raziskavi sodelovalo 18 ali 27,27-odstotni delež vzorca. 14 otrok (21,21-odstotni delež vzorca), ki so sodelovali v raziskavi, je bilo starih med 
Preglednica 2 Starost sodelujočih otrok v raziskavi

\begin{tabular}{lrr}
\hline Starost otrok & Število otrok & Delež otrok \\
\hline Do 11,5 mesecev & 3 & $4,55 \%$ \\
Od 12 do 18 mesecev & 16 & $24,24 \%$ \\
Od 18 do 24 mesecev & 18 & $27,27 \%$ \\
Od 24 do 30 mesecev & 14 & $21,21 \%$ \\
Od 30 do 36 mesecev & 15 & $22,73 \%$ \\
\hline Skupaj & 66 & $100,00 \%$ \\
\hline
\end{tabular}

dvema letoma in dvema letoma in pol. Najstarejših otrok, starih med dvema letoma in pol in tremi leti, je bilo 15 (22,73-odstotni delež vzorca).

$\checkmark$ raziskavi je sodelovalo 31 deklic ali 47-odstotni odstotni delež vzorca in 35 dečkov ali 53-odstotni delež vzorca.

\section{Potek raziskave}

Raziskavo smo izvajali v marcu 2014. Najprej smo se o njenem poteku pogovorili z vzgojiteljicami predšolskih otrok, ki so nam pomagale izvesti raziskavo, saj so otroke poznale in tako lažje zapisovale njihova opažanja ob poslušanju izbrane glasbe in prosti igri.

Pripravili smo soglasja za starše oz. skrbnike otrok. V raziskavi so sodelovali vsi otroci, za katere smo prejeli podpisana soglasja. Vsi podatki, ki smo jih z raziskavo pridobili, so tajni in uporabljeni zgolj v raziskovalne namene.

$\mathrm{V}$ raziskavi je sodelovalo 66 otrok prve starostne skupine. Otroci so se v dopoldanskem času, po dopoldanski malici, 20 minut ob poljubni igri lahko prosto gibali med tremi različnimi igralnicami, med katerimi so imeli prost prehod. Igralnice so bile zvočno izolirane. $V$ vsaki igralnici se je predvajala glasba in so bile na mizicah enake namizne igre, s čimer smo želeli zadostiti pogoju, da bi se otroci iz igralnice v igralnico sprehajali zaradi všečnosti predvajane glasbe, in ne namiznih iger.

V prvi igralnici smo predvajali izbrane aktualne popevke, ki jih trenutno poslušamo po radijskih postajah. Popularna glasba, katere besedila navadno otroci niti ne razumejo, lahko vključuje elemente rocka, hip hopa, reggaeja, plesne glasbe, jazza, elektronske glasbe in drugih zvrsti. Ker si popularna glasba predvsem prizadeva biti priljubljena množicam in posledično dobro prodajan tržni predmet, je po našem mnenju vsebinsko nezahtevna, večinoma neizvirna ter šablonsko oblikovana. Ritmični, harmonski in melodični vzorci popevk so večinoma preprosti, besedila pogosto obravnavajo ljubezensko tematiko, ki otrokom niti ni blizu, njihova kitična zgradba največkrat vsebuje tudi refren. 
V drugi igralnici smo predvajali posnetke klasične glasbe - izbrane skladbe z zgoščenke Mozart in Motion (Campbell 1983), ki vsebuje odlomke Mozartovih skladb. Skladbe smo izbrali zato, ker so različne študije pokazale, da ima Mozartova glasba pozitiven vpliv na intelektualni in ustvarjalni razvoj otroka (Campbell 2004).

$V$ tretji igralnici so otroci lahko poslušali otroške pesmice $z$ instrumentalno spremljavo in brez nje, ki jih poje Otroški pevski zbor RTVS. Izbrali smo otroške pesmi Janeza Bitenca. Otroci so poslušali skladbe, posnete na prvi zgoščenki Mavrica (Bitenc 2008). Te pesmice smo izbrali, saj smo mnenja, da je avtor besedil in skladatelj znal poiskati idealno sozvočje med besedo in melodijo. Iz besedil pesmic lahko vidimo, da je avtor izhajal predvsem iz bogastva otroškega doživljanja in to domišljijo, nežnost in lepoto znal prenesti v glasbeno sporočilo, ki se nas vedno dotakne. Preproste Bitenčeve melodije upoštevajo tudi obseg otroškega glasu.

Vse tri igralnice je bile preprosto opremljene $z$ nekaj omarami ob steni ter $s$ štirimi mizami na sredini, na katerih so bile zložene namizne igre: puzzle, vstavljanke, nizanke, kocke, kocke za razvrščanje, urejanje, vstavljanje, nizanje. Iger je bilo v igralnici dovolj za vse otroke, ki so se hkrati sprehajali iz igralnice $v$ igralnico in se igrali ob zvočni kulisi.

Vzgojiteljice so za vsakega otroka merile in si zapisovale čas njegovega zadrževanja $v$ posamezni igralnici, kjer se je predvajala različna glasba. Zapisovale so si, kolikokrat so se otroci vračali v posamezno igralnico, kašne so bile njihove reakcije ob slišani glasbi (petje pesmic, gibanje, ples $z$ drugimi otroki ...) ter kaj so ob poslušanju zvočne kulise počeli.

\section{Rezultati in interpretacija}

Otroci so se 20 minut sprehajali iz ene igralnice $v$ drugo in se ob igrah na mizi in v različnih kotičkih različne igre igrali sami, v dvojicah ali največ $v$ skupini po tri. Na mizah so imeli v vseh treh igralnicah enake otroške namizne igre. Otrokom smo pred pričetkom raziskave povedali, da se lahko prosto sprehajajo po igralnicah. Preden smo začeli predvajati glasbo, smo si z otroki ogledali vse igre v vseh igralnicah in jim razložili pravila pri posameznih igrah.

\section{Otrokovo vedenje ob zvočni kulisi v posamezni igralnici ter sodelovanje $z$ drugimi}

Otroci so bili najprej v igralnici, kjer se je poslušalo aktualne popevke, torej glasbo, ki jo lahko slišijo vsak dan na različnih radijskih postajah. $V$ tej igralnici so bili zelo razigrani, glasni in pri igrah je prišlo do kreganja in izločevanja. Nekateri otroci so bili agresivni do drugih in so jemali igrače drugim otrokom 
iz rok. Otroci so se ob poslušanju te glasbe gibali z intenzivnimi in veliki gibi. Ko so se v glasbi ponavljali zvočni vzorci, so otroci to prikazali s ponovljenimi gibalnimi vzorci. Podobno ugotavlja tudi Borota (2013). M. Videmšek in Pišot (2007) govorita o ustvarjalnem gibu, s katerim otrok izrazi doživetja ob glasbi, spremlja glasbeni potek ali z njim vizualizira glasbene predstave o elementih glasbe (krajši, daljši, višji in nižji toni, hitro, počasi ter glasno in tiho).

Otroci v drugi igralnici, kjer so poslušali klasično glasbo, so se ob vstopu $v$ prostor zelo umirili. $V$ največjih primerih so se mirno usedli za mizo k prostim igračam in se igrali samostojno. Ob glasbi so se vidno umirjeno gibali. Nekateri so od igre vstali in po igralnici zaplesali. Opazili smo, da so se otroci, ko so bili v skladbi slišati nizki toni, gibali predvsem z oponašanjem gibanja baletk z nogami. Visoke tonske lege in slišane svetle barve zvoka violine pa so pri otrocih spodbudili gibanje $z$ rokami. Podobno ugotavlja tudi Borota (2013), ki je opazila nekatere ustaljene vzorce gibanja v povezavi z njihovim doživljanjem glasbe.

Otroci v tretji igralnici so bili ob različnih skladbah z instrumentalno spremljavo ali brez nje pri igri zelo sproščeni in razigrani. Ne moremo sicer trditi, da so otroci pesmi poznali, saj on njih niso vsi prepevali, so se pa ob glasbi gibali in si pripevali na nevtralne zloge. Nekaj deklic je tudi zaplesalo v paru. Zelo nazorno so ob plesu prikazali tudi čustva, ki jih je v njih spodbudilo poslušanje te glasbe. Ob plesu so $z$ dvignjenimi rokami nad glavo in z obrazno mimiko pokazali občutek veselja in zadovoljstva. Otroci so se ob namiznih igrah mirno pogovarjali in se pri igri pridruževali drugim otrokom - največ $v$ dvojicah, nekaj otrok se je igralo tudi v skupini po tri. M. Zagorc (1997) ugotavlja, da otroci veliko bolj izražajo svoje duševno počutje s telesnim izražanjem kot odrasli. Trdi, da imata gibanje in čustvovanje veliko skupnega, saj se vsa čustva kažejo v ekspresivni govorici telesa. Predvsem otroci in mladostniki najdejo posebno zadovoljstvo v plesu, »kajti mnogi med njimi odkrijejo $\checkmark$ njem pot za osvoboditev svojih čustev in občutij, ki bi jih s pomočjo besed težko izrazili« (Zagorc 1997, 18). Nadalje ugotavlja, da plesno gibanje izjemno prispeva k samozavedanju, občutenju uspeha in zadovoljstva, saj omogoča oblikovanje ustrezne telesne slike in vliva samozadovoljstvo, vpliva na vedenje, odnos do drugih in oblikovanje stališč (Zagorc 1997, 18).

Tudi A. Pesek (1997) ugotavlja, da otroci z gibanjem izražajo različne glasbene značilnosti, kot so razpoloženja $v$ glasbi (veselo - žalostno), tempo in spremembe tempa s spreminjanjem hitrosti gibanja, dinamiko ter dinamične spremembe $z$ različno količino energije $v$ gibih, s hojo po prstih pri tihi glasbi ter stopanjem po celem podplatu pri glasni, tonsko višino $z$ gibanjem v visokih položajih pri visokih tonih in nizkih položajih pri nizkih tonih, ritem z 
Preglednica 3 Povprečne vrednosti in delež časa, preživetega v posamezni igralnici

\begin{tabular}{lrr}
\hline Igralnica z glasbo ... & Povprečen čas & Delež časa \\
\hline Aktualne popevke & 4,60 minute & $23,0 \%$ \\
Klasična glasba (Campbell 1983) & 7,08 minute & $35,4 \%$ \\
Otroške pesmice (Bitenc 2008) & 8,32 minute & $41,6 \%$ \\
\hline Skupaj & 20,00 minut & $100,0 \%$ \\
\hline
\end{tabular}

zadrževanjem gibov pri dolgih tonih in s kratkimi, odsekanimi potezami pri kratkih tonih, akcent $z$ uporabo poudarjenih gibov, dobo s stalnim gibanjem na glasbeni pulz, repeticijo in kontrast s ponavljanjem ali spreminjanjem določenih telesnih gibov ter katerekoli spremembe $v$ glasbi s spreminjanjem sloga, smeri ali stopnje intenzivnosti gibanja.

\section{Čas, preživet $v$ posameznih igralnicah, in prehajanje med igralnicami}

V spodnji preglednici so predstavljene povprečne vrednosti časa, ki so ga otroci preživeli v posamezni igralnici. Vzgojiteljice so si za vsakega otroka zapisovale čas, ki ga je preživel v posamezni igralnic; izračunali smo povprečne vrednosti (preglednica 3).

V prvi igralnici, kjer so lahko otroci poslušali aktualne popevke, so se zadrževali v povprečju najmanj časa: 4,60 minute ali $23 \%$ časa, ki so ga imeli na razpolago za prosto igro. Največ časa, v povprečju za 15 sekund dlje, so se $v$ tej skupini zadrževali najstarejši otroci, torej otroci, stari med dvema letoma in pol ter tremi leti. Predvidevamo, da se pri teh otrocih lahko že občuti vpliv vsakodnevnih glasbenih sporedov radia, televizije in poslušanja glasbe njihovih staršev, starejših sorojencev. Skoraj vsi otroci, ki so to igralnico zapustili in se šli igrat $z$ igračami $v$ drugih dveh igralnicah, se $v$ to skupino niso vrnili, z izjemo dveh najstarejših dečkov, ki se tja nista vrnila hkrati.

$V$ drugi igralnici so otroci preživeli v povprečju 7,08 minute ali 35,4\% časa, ki so ga imeli na razpolago za prosto igro. $V$ to igralnico so se otroci, ko so skupino zapustili, še vračali - v glavnem iz igralnice s predvajano otroško glasbo in nazaj.

Otroci, so se ob igri v povprečju največ časa zadrževali v igralnici, kjer so lahko poslušali otroške pesmice Janeza Bitenca. $V$ tej igralnici so preživeli $v$ povprečju 8,32 minute ali $41,6 \%$ časa, ki so ga imeli na razpolago za prosto igro.

Otroci so bili najprej v igralnici, kjer so se izvajale aktualne popevke. Po določenem času so odšli v drugo ali tretjo igralnico. Iz igralnice, kjer smo predvajali otroške pesmice, so se otroci vrnili še v igralnico, kjer so lahko slišali 
klasično glasbo. $V$ igralnico s popevkami pa sta se vrnila samo dva najstarejša dečka (3,03-odstotni delež vzorca). Ko so otroci enkrat prišli v igralnico $s$ predvajanimi otroškimi pesmicami, $v$ večini te niso več zapustili. $V$ igralnico $s$ klasično glasbo je iz igralnice $z$ otroškimi pesmicami ponovno šlo le sedem otrok ali 10,61-odstotni delež vzorca.

\section{Sklepne ugotovitve}

V študiji primera, ki smo jo izvedli v marcu 2014, nas je zanimalo, kako so se otroci prve starostne skupine vedli v igralnicah, kjer se je predvajala različna glasba. Vzgojiteljice otrok so merile in si zapisovale čas zadrževanja vsakega otroka v posamezni igralnici, kolikokrat so se v posamezno igralnico vrnili in kaj so ob poslušanju zvočne kulise počeli. Zapisovale so si tudi reakcije otrok ob slišani glasbi (petje pesmic, gibanje, ples z drugimi otroki ...). Otroci, ki so sodelovali v raziskavi, so večino, kar $41,60 \%$ časa, ki so ga imeli na razpolago ob prosti igri, preživeli v igralnici, kjer so se vrtele umetne otroške pesmice. Ob tej glasbi so se otroci mirno igrali in se $v$ igri povezovali tudi $z$ drugimi otroci. Predvidevamo, da so se $v$ tej igralnici zadrževali ravno zaradi tega, ker so glasbo razumeli, jo podoživeli, se z njo poistovetili in jo ponotranjili. Menimo, da so bili otrokom bližja predvsem preprostost melodije, ritma in harmonije ter besedila, ko so jih razumeli.

Nekomercialno umetno glasbo običajno poimenujemo klasična glasba, ne glede na čas, v katerem je nastala. Poslušanje klasične glasbe pa v primerjavi s komercialno zahteva mir, čas, zbranost, usmerjeno pozornost, ustvarjalnost, razvite glasbene sposobnosti in znanje. Tudi otroci so se, ko so vstopili v igralnico, kjer se je vrtela klasična glasba, umirili in mirno igrali z igračo, ki so si jo izbrali. V povprečju so se $v$ tej igralnici zadrževali $35,40 \%$ časa, ki so ga imeli namenjenega prosti igri ob zvočni kulisi. $V$ tej igralnici se otroci $v$ igri niso povezovali v dvojice, so se pa tisti, ki so igralnico zapustili, vanjo še vrnili.

Pojem komercialna glasba združuje vse zvrsti umetne glasbe, od narodno zabavne do popa in drugih zvrsti, ki jih ponuja komercialna glasbena industrija, ta vrsta glasbe pa je namenjena predvsem sproščanju, zabavi in ustvarjanju različnih razpoloženj. Njen namen je, da deluje na poslušalca predvsem $z$ všečnimi, ponavljajočimi se glasbenimi motivi v minimalnem glasovnem obsegu. V igralnici, kjer so se vrtele aktualne popevke, take, ki jih otroci slišijo po radijskih in televizijskih sprejemnikih, so se zadrževali najmanj, le 23,00\% časa, ki so ga imeli na razpolago za prosto igro. Ob taki glasbi, ki je niti ne razumejo, so postali agresivni in $v$ nekaj primerih je morala $v$ kreganje za isto igračo poseči tudi vzgojiteljica. $Z$ izjemo dveh najstarejših dečkov se $v$ to igralnico, ko so jo zapustili, ni vrnil nihče več. 
Umetniške dejavnosti, tudi poslušanje glasbe, so pomemben in spodbuden del učenja tudi na drugih področjih. Zato se moramo tisti, ki otrokom glasbene dejavnosti izbiramo, zavedati, da vse, kar je dobro za odrasle, ni vedno dobro tudi za otroke.

\section{Zahvala}

Rada bi se zahvalila dr. Mirku Slosarju za usmerjanje, napotke, zaupanje in pomoč, ne samo pri nastajanju tega članka, ampak pri moji rasti od pisanja diplomskega dela naprej. Zato ta članek posvečam njemu.

\section{Literatura}

Bitenc, J. (2008). Mavrica: 100 najlepših otroških pesmic. CD. Ljubljana: RTV Slovenija.

Benkovič, B. 2011. »Socialni in čustven razvoj predšolskega otroka.« V Socialni in čustveni razvoj predšolskega otroka: 4. mednarodna strokovna konferenca vzgojiteljev v vrtcih, ur. M. Željeznov Seničar in E. Šelih, 7-14. Ljubljana: MiB

Borota, B. 2013. Glasbene dejavnosti in vsebine. Koper: Annales.

Campbell, D. G. (1983). The Mozart Effect: Music for children. Zv. 3, Mozart in Motion. CD. B. k.: Magnamusic Baton.

Campbell, D. G. 2004. Mozart za otroke: prebujanje otrokove ustvarjalnosti in mišljenja s pomočjo glasbe. Ljubljana: Tangram.

Clinic, M. 2001. Vse o nosečnosti in otrokovem prvem letu. Ljubljana: Educy.

Denac, O. 2002. Glasba pri celostnem razvoju otrokove osebnosti: priročnik za vzgojitelje, razredne učitelje, učitelje glasbe in glasbenih predmetov $v$ splošnem šolstvu in glasbenih šolah. Ljubljana: Zavod Republike Slovenije za šolstvo.

Gallahue, D. L., in J. C. Ozmun. 2006. »Motor Development in Early Childhood Education." V Handbook of Research on the Education of Young Children, ur. B. Spodek in O. Saracho, 105-120. Mahwah, NJ: Lawrence Erlbaum.

Hargreaves, D. (1990). The Developement Psychology of Music. Cambridge: Cambridge University Press.

Kožman, P. 2011. »Spoznavanje čustev v oddelku eno do dvoletnih in v oddelku dve do triletnih otrok. « V Socialni in čustveni razvoj predšolskega otroka: 4. mednarodna strokovna konferenca vzgojiteljev $v$ vrtcih, ur. M. Željeznov Seničar, M. in E. Šelih, 144-150. Ljubljana: MiB.

Kranjc, M. 2011. „Socialni in čustveni razvoj predšolskega otroka v starostno kombiniranih skupinah." V Socialni in čustveni razvoj predšolskega otroka: 4. mednarodna strokovna konferenca vzgojiteljev $v$ vrtcih, ur. M. Željeznov Seničar, M. in E. Šelih, 151-158. Ljubljana: MiB.

Ministrstvo za šolstvo in šport. 1999. Kurikulum za vrtce: predšolska vzgoja v vrtcih. Ljubljana: Ministrstvo za šolstvo in šport.

Lundin, R. W. 1967. An Objective Psychology of Music. New York: Ronald. 
Marjanovič Umek, L., in M. Zupančič. 2009. Razvojna psihologija: izbrane teme. Ljubljana: Znanstvena založba Filozofske fakultete Univerze v Ljubljani.

McKernon, P. E. 1979. »The Development of First Songs in Young Children. « New Directions for Child and Adolescent Development, št. 3: 43-58.

Mesec, B. 1998. Uvod v kvalitativno raziskovanje $v$ socialnem delu. Ljubljana: Visoka šola za socialno delo.

Moog, H. 1976. »The Development of Musical Experience in Children of PreSchool Age.« Psychology of Music 4 (2): 38-45.

Ostwald, P. F. 1973. »Musical Behavior in Early Childhood." Developmental Medicine \& Child Neurology 15 (3): 367-375.

Piaget, J. 1952. The Origins of Intelligence in Children. New York: International Universities Press.

Pesek, A. 1997. Otroci v svetu glasbe: izbrana poglavja iz glasbene psihologije in pedagogike. Ljubljana: Založba mladinska knjiga.

Revesz, G. 1954. Introduction to the Psychology of Music. Norman, OK: University of Oklahoma Press.

Shuter-Dyson, R., in C. Gabriel. (1981). The Psychology of Musical Ability. London: Methuen.

Sicherl Kafol, B. 2001. Celostna glasbena vzgoja. Ljubljana: Debora.

Slosar, M. 1995. »Dejavniki uspešnosti razrednih učiteljev pri glasbeni vzgoji na razredni stopnji osnovne šole.« Doktorska disertacija, Univerza v Ljubljani.

Smolej, B. 1996. »Razvoj glasbenih sposobnosti.« Psihološka obzorja 5 (1): 77-88.

Starc, B., in M. Markočić. 2004. Osobine i psihološki uvjeti razvoja djeteta predškolske dobi: priručnikza odgojitelje, roditelje i sve koji odgajaju djecu predškolske dobi. Zagreb: Golden marketing.

Šivic, P. 1975. »K zbirki Pojem - plešem. « Grlica, revija za glasbeno vzgojo 18 (1-2): 1-2.

Videmšek, M., P. Berdajs in D. Karpljuk. 2003. Mali športnik. Ljubljana: Fakulteta za šport.

Videmšek, M., in R. Pišot. 2007. Šport za najmlajše. Ljubljana: Fakulteta za šport Wing, H. D. 1961. Standardized Test of Musical Intelligence. Upton Park: Taylor \& Francis.

Zagorc, M. 1997. »Ples - ustvarjanje z gibom.« Ljubljana: Fakulteta za šport.

\section{Typical Behaviour of the Children of First Age Group in Playrooms with Different Music Genres}

Today, music as a psychological phenomenon in everyday life is widespread and accessible to everyone as never before. We can listen to music in the car, through our smartphones on the headphones, through radio or television sets ... We can choose the music we listen to ourselves. Can children of the first age group in kindergarten choose it for themselves? In kindergarten mu- 
sic is chosen by nursery teachers. We expect them to have developed musical abilities and skills, musical creativity and possess knowledge, namely, all those musical abilities that are important for a child's successful musical development. Which playrooms with different music genres children chose by themselves to stay for longest amount of time was determined by a study that took place in five kindergartens in the Primorska Region of Slovenia. The study included 66 children of the first age group. We offered the children to choose three music genres. In three playrooms, where we played the music, various table games were available to children. We concluded that children preferred staying in the playroom where nursery rhymes were played.

Keywords: children's integrated development in the first age group, children's musical development in the first age group, musical art in kindergartens, listening to music, musical culture 